World Lumen Congress 2021 | May 26-30, 2021 |

Iasi, Romania

\title{
Rethinking the Communication with the Unions Members in the New Context
}

\author{
Vasile HODOROGEA, Tulia Maria CĂŞVEAN
}

https://doi.org/10.18662/wlc2021/29

How to cite: Hodorogea, V., \& Căşvean, T. M. (2021). Rethinking the Communication with the Unions Members in the New Context. In A. Sandu (vol. ed.), Lumen Proceedings: Vol. 17 World Lumen Congress 2021 (pp. 308-317). Iasi, Romania: LUMEN Publishing House. https://doi.org/10.18662/wlc2021/29 


\title{
Rethinking the Communication with the Unions Members in the New Context
}

\author{
Vasile HODOROGEA', Tulia Maria CĂȘVEAN²
}

\begin{abstract}
Additional to the three main trends influencing social dialogue at the organizational level-de-centralization, up-scaling, de-institutionalization and representation - the COVID-19 pandemic rules brought a new influence that impacts the Unions, forcing it to adapt its internal communication. This paper is centred upon the way the Unions members in Romania get access to information in the new labour landscape, characterized by the work from home and physical distancing. The research focuses on a collective case-study of three strong Union Federations that developed internal communication with unions' members that fits the pandemic context. The research focuses on the internal communication repertoire elements used by the Unions. The research method assesses the qualitative information gathered by interviewing key Unions representatives. The main areas of interest are the key topics addressed in the communication with the members, the tools and media mix used, the frequency of the formal communication with the trade unions members, the accountable and the responsible persons with the internal communication, and the management of the feedback from the members, all in the context of what is different vs. 2019. The conclusions are enriched with some recommendations for future development of communication with union members, supporting the social dialog.
\end{abstract}

Keywords: Union communication, internal communication, digital, pandemic, social dialog.

\section{Introduction}

Industry 4.0, internet of things, big data, robotics, and constant innovation in production technologies are the vectors of the new reality that changes the way people work and relate to employers. Green business, climate change, gender balance and equality in the labour market, growing globalization are also affecting labour relations. In this new context, informing, consulting, negotiating, and reaching agreements are key factors for social peace. These four key vectors are the foundation for the social dialog, defined by the International Labour Organization

\footnotetext{
1 Doctor in Communication Science, University of Bucharest, Bucharest, Romania. E-mail: vasile.hodorogea@unibuc.ro

2 Doctor in Communication Science, University of Bucharest, Bucharest, Romania. E-mail: tulia.casvean@unibuc.ro
} 
$(\mathrm{ILO})^{3}$ as a voluntary act of informing, consulting, and negotiating social agreements between partners, as well as negotiating collective labour agreements. Either tripartite or bipartite, the social dialog is considered a direct way of exercising economic and social democracy (Iliescu \& Butucescu, 2019, p. 181). Additional to the three main trends influencing social dialogue at the organizational level (Euwema et al., 2015, pp. 6-7) - de-centralization, up-scaling, de-institutionalization and representation - the COVID-19 pandemic rules (work from home or telemunca, social distancing) brought a new influence that impacts all three participants in the social dialog defined by the Romanian $l_{a w}{ }^{4}$ : the employees, represented either by Unions or by the employees' representatives who deal with the management, the employer organization (patronate), and the government.

A key aspect of social dialog is trust, that is not a control mechanism but a substitute for control, reflecting a positive attitude about another's motives (Rousseau, 1998, p. 399). Trust leads, as Euwema and his colleagues observe, to more cooperative negotiation behaviours, while low trust leads to more competitive behaviours (Euwema et al., 2015, p. 10). Therefore, trust has been an object of research related to a critical competence in employment relations, whenever it comes to any relations between parties through cross-functional teams, temporary groups, strategic alliances, and socially embedded partnerships (Lewicki et al., 1998, p. 438). As remarqued by Rousseau and her colleagues, interpersonal and inter-organizational trust are different, yet being built on the same definitory elements: acceptance of the vulnerability based upon positive expectations of the intentions or behaviour of another (Rousseau et al., 1998, p. 395).

Trust and trustworthiness highly influence the quality of social dialog, when manifest among involved parties and within the organization. In case of Unions, the commitment of the leaders is an important factor that influences the members' trust, before they support their participation in the decision-making processes of the organization (Euwema et al., 2015, p. 10).

The scholar literature shows a clear interest towards the institutional trust manifested as a relationship between the social dialog parties, towards how trust is built or how distrust appears (Euwema et al., 2015; Pop, 2012'; Radu, 2008; Scharpf, 2002). The mechanisms that underpin trust were, as well, largely studied in relationship with the management of communication, reputation and organizational image (Coman, 2001; Conelissen, 2004; Krone, 2005; Mumby \& Stohl, 1996; van Riel, 1999; van Riel \& Fomburn, 2007; Watson \& Kitchen, 2008). Up to now, far too little attention has been paid to how Trade Unions communicate internally with their members. The aim of the current study is to enrich the research literature, focusing on how key Romanian Trade Unions (Federations) run the communication with members and how they adapt to the current context, focusing on the internal communication axis, that enable organizations (Trade Unions) to achieve their objective to gain the trust of their members.

\footnotetext{
3 https://www.ilo.org

${ }^{4}$ Law no. 62/2011, Social Dialog Law, with subsequent amendments (Legea nr. 62/2011 - Legea dialogului social, cu modificările şi completările ulterioare).
} 


\section{Internal communication beyond the criticism of the organizational communication}

Multidisciplinary scholars researching the managerial or business communication focus their studies on three key factors present in all organizations: people, objectives, and the structure they put in place for monitoring the environment and for generating the strategies to adapt to it (Coman, 2001, p. 6). There is thus a dynamic relationship between communication and organization captured by Mumby (2013, p. 37) in his working definition for organizational communication: the process of creating and negotiating collective, coordinated systems of meaning through symbolic practices oriented toward the achievement of organizational goals.

Internal communication is virtually present in any organization, influencing the workplace efficiency. Other keywords used by scholars and practitioners, reflecting the action of communicating with organizational members, are reviewed by Welch and Jackson (2007, p. 178), who mention they are interchangeable: corporate communication, internal relations, employee communication, internal communications, employee relations, internal public relations, and stuff communication. Due to its specificity, trade union members communication could be added to this list. Yet, for in paper, we will refer to union members communication as internal communication.

In order to understand the process of organizational communication and to have a holistic view of it, it is necessary to ensure an interdisciplinary harmonized approach. Such a perspective requires the inclusion of the opinion of the specialists in various fields such as public relations, corporate communication, marketing, and organizational management, about organization communication, coagulating convergent points that, as Hatch and Schultz (2000, p. 19) suggest, offers the possibility of analysis at the organizational level. Van Riel and Fomburn (2007, p. 2) identify the organization's communication system as a collection of multiple tactical and strategic environments on which to rely to communicate with stakeholders, additional to the message the organization chooses to disseminate through these media, concluding that the communication process within an organization is a set of activities involved in managing and orchestrating internal and external communication, aimed at creating favourable perception among stakeholders who massively influence the company (p. 25).

The internal communication definition gaps in literature, were critically reviewed by Welch \& Jackson (2007, pp. 181-183) who propose a new summative definition that highlights key attributes of the internal communication: the strategic management of interactions and relationships between stakeholders at all levels within the organization (p. 183). In addition to this definition, we consider that internal communication is a formal effort aiming for a clear purpose. Internal communication systems aim to enable the organization to achieve its objectives by having a role to play in developing employee commitment and trust (Welch \& Jackson, 2007, p. 190), and by building consensus focusing on symbolic use of language, on how organizations function, and what their goals are (Mumby \& Stohl, 1996). As Holtz (2002, p. 271) states, when interacting with various stakeholder audiences, employee (in our case, 
trade union members) should behave in a manner that reinforces the way the organization wants those audience to feel when they hear or think about the organization.

For the economy of this study, the clarification pointed out by Cheney and Christensen, is necessary: the fuzzy organizational boundaries, emphasized by the technological progress, shows that employees (in the present paper, the trade union members) have a dual stakeholder role, being driven by the members relations, statements of mission and organizational development (Cheney \& Christensen, 2001, p. 231).

Dissemination of information is done towards multiple stakeholders, internal and external, in an attempt to influence the behaviour of audiences, organizations developing, as Grunig and Hunt (1984, p. 23) suggest, a formal function of communication when the organization or its audiences behave in a way that has consequences for the other party. The same point of view is shared by Van Riel and Fomburn who point out that the dissemination of information is done by a variety of specialists of the organization, with the common goal common goal of enhancing the organization's ability to retain its license to operate (Van Riel \& Fomburn 2007, p. 25).

\section{Mapping internal communication}

The relationship between the communication producer and the receiver is bi-lateral, but not necessarily symmetrical. L'Etang (2005, p. 522) argues that employees are too often treated as a single public, opening a new approach that shows the importance of different internal stakeholders' groups. Union members are not simply passive recipients of internal communication, their reacting or generating communication topics with different degrees of impact, suggesting different groups of stakeholders within the trade union members (regular members, leaders, local branch leaders, leading board).

Building on stakeholder groups at different levels in organisations, as depicted by Welch \& Jackson (2007, p. 184), in the case of unions different groups with different stakes could also be identified: all members; board leadership (elected central leaders, the President of the union); day to day leaders (local branches leaders); project teams. Among those key internal stakeholders' groups there are different communication channels, participation levels, contents of communication and feedback loops. Welch \& Jackson (2007, p. 185) argue that the strategic level is also different, being linked with the content. Projecting their findings into Unions, shows that strategic leaders (board) communicate on organizational issues (goals, objectives, new developments, activities and achievements), and the project group (local leaders) pass the information received form the central leaders and briefs on running projects or member's concern. At all members level, communication must carry information about the daily life of the organization, the organizational struggles, victories, difficulties, challenges. Regular members must be constantly informed about news and events in the union life, that will strengthen the beliefs and goals for fighting for common rights.

Mumby (2013, p. 25) identifies several factors that could generate tension between the goals, beliefs and desires of individual organizational members. A 
selection of those factors reflect union members interests in relationship with the organizational interests (Table 1). Trade Union plays a role in between the individual and the organization, representing and supporting the individual interests, based on the individual's trust and mandate. It must control the goals, beliefs and desires by informing their members about the interactions with the organization and the environment, generating members' identification. This concept was supported by Dutton and Dukerich influential study (1991), quoted by van Riel and Fomburn (2007, p. 76), that showed that employees are influenced by the interpretations people are making of the organization's actions, intentions, and identity.

Table 1. Some Tensions Between Individual and Organizational Goals, Values, and Needs (based on Mumby, 2013, p. 26)

\begin{tabular}{cc}
\hline Individual & Organization \\
\hline Maximizing salary & Maximizing profit \\
Autonomy & Commitment and constrains \\
Job stability & Organization flexibility and \\
change
\end{tabular}

Internal communication enhances identification when members perceive that they are receiving enough information about their role and what the organization as a whole is doing, and when taken seriously by their leaders (van Riel \& Fomburn, 2007, p. 76).

As in any organization, internal communication in the trade unions is a strategic approach, based on goals and objectives, resources (human resources, budgetary resources, time, technological resources, etc.), aiming to motivate members and build pride in the organization.

\section{Methodology}

Relevant existing research in internal communication field has been reviewed and primary research conducted, aiming to identify the extent to which processes and instruments described in literature can be observed in the internal communication of the strong Trade Unions (federations) in Romania. In-depth interviews with relevant Trade Union Federations and a Confederation's top leaders were applied in order to collect information about the tools, media mix used, and the type and frequency of the formal communication with the trade unions members, feedback management, role and responsibilities and differences vs. prepandemic period. This qualitative method was chosen because in contrast with other methods, the in-depth interview may reveal more details about beliefs, attitudes and behaviour of the interviewee (Hossian, 2011, p. 153), ensuring a more 
comprehensive understanding of the investigated phenomena.

The recruitment of the interviewee was possible due to personal connections (this explains also the limited number of interviews), covering two major trade unions federations and one of the most important confederation's personal with exposure and expertise on communication with members. Due to pandemic restrictions interviews could not be run face-to-face but mediated by technology, during February and April 2021. As backup, the interviewees were asked to answer to a mini-questionnaire focused on topics and questions used in exploring topics of interest for research. Based on these documents, a number of verbatims and quotations have been cited in this paper to illustrate specific examples.

\section{Findings and Discussions}

Results of this research highlight the increased interest of Unions' leadership to communicate more often with members and to get in touch with all members' layers (building and strengthening trust), because, as one of the respondents argues:

The Union must evolve form a "service provider" for its members to being a "socially active core". (I2F)

This is a direct consequence of understanding the need of membership retention, in the context of declining membership especially in the economic sector. On top of this trend, the pandemic stressed the need for clear and more information and stronger protection for members (income, employment, safety and health at work) in the context of high economic contraction and declining companies' income. As some of the respondents remarqued, the main communication campaigns focused on:

Retention actions, information campaigns, additional support for additional rights adapted the new Covid reality. (I1S)

Safety and health in the Covid context, new working schedule, fair payment, rights and benefits protections, job protections and voluntary vacancy, respecting the rights from Collective Labour Contracts. (I2F)

Tele-work (work from home) and the wide-spread access to technology are key factors that intertwined the offline and online communication tools. Despite the increasing of online communication (emails, WhatsApp groups, Facebook pages, internal apps, owned website), face-to-face, flyers, and print communication displayed on dedicated boards were still used during the pandemic period. As well, middle level leaders (local leaders) continued to communicate directly with members on local and specific issues:

It is good to be connected with modern communication technology, yet, in each local organization, leaders must continue to discuss face to face with members about their daily problems, about their need, about the respect they get from the company management. This is the only way we can get in touch with the real problems of our members. (I2F)

This need for direct contact with members shows the fact that members 
need "a face that fight for their rights", that are close to them, and who's gaining their trust with the results they bring.

The pandemic period increases the dialog within Unions, feedback form members being more valued, and a horizontal dialog being now in place more often than the pre-pandemic years.

All signals from members are valuable. They need to know that their opinion is heard and somebody represents them. This is way, our efforts increased for giving answers to all emails we received form our members. (I2F)

We asked feedback on all key initiative from our local leaders. In some topics, we asked comments and opinions form all our members too. (I1S)

The study suggests that, despite the effort of Unions to answer to the emails from members, the one-way model of communication is still in place when come to social media where the engagement with members and non-members is still at low levels.

As well, the public discourse generated important conversations for Unions, being translated into internal communication topics:

We have observed that some topics are very active in mass-media (rules on technical unemployment, vaccination, central authorities' attitudes towards Unions), creating conversations that our members were interested in too. (I1S)

At the beginning of the pandemic situation, the topics addressed within the Unions covered, as expected, a high interest for safety and health: internal announcements focused on sanitary protection measures, physical distance and, or avoidance of personal contacts, providing protective equipment (masks, gloves, boots, etc.).

We put a lot of additional effort to communicate anti-pandemic protection measurements, the new working way in this new context, how to approach the tele-working and health and safety (SSM) for it. (I3C)

Unions build on members' identification stressing the need of financial protection measures in the context of COVID-19, communicating with their members new addendums signed with companies on this topic. Other subjects communicated to members covered negotiations' evolutions for Collective Labour Contract (reaching terms of new addendums), advices for employees made redundant or negotiations for technically unemployment, new working program and payments.

We fought for obtaining representativeness at the level of unit groups, work from home, flexibility of activity, new opportunities for a new job. All were communicated to our members who need information and clarity about the situation of jobs in the context of Covid. (I1S)

At all members level, this communication carried information about the daily life of the trade unions, the unions' struggles, victories, difficulties, challenges. Nevertheless, there were positive messages for members, highlighting special dates such: anniversary, the day of workers in a specific sector, Easter, Christmas, National Day, etc. In all those messages, "the solidarity" and "Unions' values" were stressed, 
creating a positive influence on members' attitudes on their union. We noticed that in this soft communication area, there were a decline in communication for personal events (pensions, new members, new local leaders, etc.), pointing out that "individual events" are less important that "common achievements" during this period.

2020 was an active year for Unions that protested in street claiming rights protections. When these actions took place, the internal communication had a hype, multiple channels being used, including external communication (prese releases, open letters, messages boards, interviews etc.) that reinforced unions' power and solidarity.

We do what we do for our members and they must find out about our actions for protecting their rights and working places. We must have a "strong heard and listened voice" every time we run a protest, and media amplifies it, helping reaching more of our members. (I2F)

An interesting finding is that the studied trade unions have not used paid communication (adds, advertorials, etc.), but they increased the frequency, moving from sporadic communication (when notable events take place in the trade union life only) to 2-3 weekly messages via different channels, most of it new: Emails, Facebook, Whats App groups, Internal Apps.

Due to the need of physical distancing, we had to find new, alternative ways to communicate with our members. Digital channels such Whats App groups or a new app for members allowed us to be better connected with our members. (I3C)

The increase on communication frequency was driven by a higher need of official information about the sanitary measures in the context of the COVID-19 pandemic, the changes in the labor market developments (redundancies, dismissals, changes in income rights), the new dynamics of trade union life and the increased need to inform members about union activity.

The increasing communication needs driven an increase of number of people covering this kind of tasks. Nonetheless, in all cases, the content is approved at the highest level in unions' organisation (by the President, Vice-President, or by the highlevel leaders).

A key take-out from the interviews indicated that trade unions use internal communication for informing and constant interaction with members, for creating emotional bonding between leaders and all members. The objectives are to inspire people to become passionate vectors for spreading the unions' messages and to promote the dialog based on transparency that driven engagement for unions' causes.

\section{Conclusions}

The results presented above provide some relevant contributions to a better understanding of trade union orientation to renewal their "contract" with members via a more active and transparent communication, addressing a gap in literature. Nevertheless, there is still a paucity of studies conducted about Romanian Trade Unions communication strategies and tactics, that must be further researched in both qualitative and quantitative approaches.

Current study showed that trade union organizations focused more on 
internal communication during the pandemic period, accessing multiple points of interaction and communication technologies. The need for clear and constant information, the changed way of communication with members (mediated by technology rather than face-to-face), and the need for adaptability to the current situation (new agenda including the new, different members' needs) increased the intensity of communication with members, bringing new topics on the table. Moreover, the studied Trade Unions communicated more often, more topics, involving more people in communication tasks with clear objective to strengthen the trust in leaders and in their actions.

We can also conclude that trade unions embraced new tools and technologies for communicating internally, paying more attention to this aspect of the trade union life. The technology is widely used to facilitate communication with members (some developed internal apps), yet trust is further strengthened through face-to-face meetings and results in negotiations with management/shareholders.

Another conclusion of this paper is that the constant information of members about news and events in the trade unions' life, common achievements and progress showed in fighting for rights, strengthen the members' beliefs and goals, motivating to further fight for common rights.

Although this research brings some important contribution for a better understanding of this topic, it has certain limitations. Firstly, this study covers only three Trade Union Organisations, therefore generalisation should be carefully carried out, additional studies being necessary to cover the trade union movement in Romania (both private and public sector). Further studies must also include opinions and attitudes of regular members about the effectiveness of internal communication.

\section{References}

Cheney, G., \& Christensen, L. T. (2001). Organizational identity: linkages between internal and external communication. In F. M. Jablin \& L. L. Putnam (Eds.), New Handbook of Organizational (pp. 231-269). SAGE Publications.

Coman, C. (2001). Relațiile publice: principii și strategï [Public relations: principles and strategies]. Polirom.

Conelissen, J. P. (2004). Corporate Communications. Theory and Practice. SAGE Publications.

Euwema, M., García, A. B., Munduate, L., Elgoibar, P., \& Pender, E. (2015). Employee Representatives in European Organizations. In M. Euwema, (Eds.), Promoting Social Dialogue in European Organizations. Human Resources Management and Constructive Conflict Management. Industrial Relations \& Conflict Management, 1 (pp. 1-18). Springer Cham Heidelberg.

Grunig, J. E., \& Hunt, T. (1984). Managing Public Relations. Holt, Rinehart and Winston.

Hatch, M. J., \& Schultz, M. (2000). Scaling the Tower of Babel: Relational Differences between Identity, Land Culture in Organizations. In M. Schultz, M. Hatch, \& M. Larsen (Eds.), The Expressive Organization (pp. 11-35). Oxford University Press. 
Holtz, S. (2002). Public Relations on the Net. Winning Strategies to Inform and Influence the Media, the Investment Community, the Government, the Public, and More! (2nd ed). American Management Association.

Hossian, D. M. (2011). Qualitative Research Process. Postmodern Openings, 2(7), 143-156. http://postmodernopenings.com/wp-content/uploads/2011/10/PO-7-102.pdf

Iliescu, D., \& Butucescu, A. (2019). Mediation and Conciliation in Collective Labor Conflicts. In M. C. Euwema, F. J. Medina, A. B. García, \& E. R. Pender (Eds.), Mediation in Collective Labor Conflicts in Romania (pp. 175-192). Springer Open.

Krone, K. J. (2005,). Trends in Organizational Communication Research: Sustaining the Discipline, Sustaining Ourselves. Communication Studies, 56(1), 95-105. https://doi.org/10.1080/0008957042000332269

L'Etang, J. (2005). Critical Public Relations: some Reflections. Public Relations Review, 31(4), 521-526. https://doi.org/10.1016/i.pubrev.2005.08.011

Lewicki, R., McAllister, D. J., \& Bies, R. J. (1998). Trust And Distrust: New Relationships and Realities. The Academy of Management Review, 23(3), 438-458. https://doi.org/10.2307/259288

Mumby, D. K. (2013). Organizational Communication. A Critical Approach. SAGE Publication Inc.

Mumby, D. K., \& Stohl, C. (1996). Disciplining Orgnizational Communication Studies. Management Communication Quaterly, 10(1), 50-72. https://doi.org/10.1177/0893318996010001004

Pop, L. M. (2012). Dialogul Social European. Ghid de informare legislativă al dialogului european. MMFPS Dialog Social.

Radu, R. (2008). Social Dialog Perspective in Romanian Road Transport. International Labour Office.

Rousseau, D. M., Camerer, C. F., \& Sitkin, S. (1998). Not So Different After All: A Crossdiscipline View of Trust. The Academy of Management Review, 23(3), 398-404. https://doi.org/10.5465/AMR.1998.926617

Scharpf, F. W. (2002). The European Social Model: Coping with the Challanges of Diversity. Journal of Common Market Studies, 40(4), 645-670. https://doi.org/10.1111/1468-5965.00392

Van Riel, C. B. (1999). Corporate communications. Prentice Hall.

Van Riel, C. B., \& Fomburn, C. J. (2007). Essential of Corporate Communication. Routlege Taylor \& Francis Group.

Watson, T., \& Kitchen, P. P. (n.d.). Corporate Communication: Reputation in Action. In T. Meleawer (Ed.), Facets of Corporate Identity, Communication and Reputation (pp. 121140). Routledge.

Welch, M., \& Jackson, P. R. (2007). Rethinking internal communication: A stakeholder approach. Corporate Communications An International Journal, 12(2), 177-198. https://doi.org/10.1108/1356328071074484 